\title{
Peningkatan Sikap Peduli Lingkungan Siswa Melalui Metode Tugas dalam Pembelajaran IPS. (Penelitian Tindakan Kelas di SMP Negeri 3 Tanjungsari Kelas VIII A)
}

\author{
Rizki Puji Rahayu \\ Prodi Pendidikan Ilmu Pengetahuan Sosial \\ Fakultas Pendidikan Ilmu Pengetahuan Sosial \\ Universitas Pendidikan Indonesia \\ rizkipujirahayu@yahoo.co.id
}

\begin{abstract}
ABSTRAK
Penelitian ini dilatarbelakangi oleh permasalahan yang ditemukan peneliti pada saat melakukan observasi awal pada tanggal 12 dan 15 Agustus 2015 yaitu rendahnya sikap peduli lingkungan siswa. Hal ini ditunjukan dengan beberapa dimensi permasalahan diantaranya rendahnya kesadaran siswa untuk membuang sampah pada tempatnya, banyaknya sampah plastik, pot bunga yang seharusnya menjadi wadah tanaman saja menjadi tercemar dengan adanya sampah, dan tanaman yang ada di dalam kelas tidak di siram. Alternatif pemecahan masalah tersebut dilakukan dengan cara memberikan tugas membuat produk dengan memanfaatkan barang bekas atau sampah yang setiap hari mereka hasilkan. Meninjau permasalahan yang akan diteliti berkaitan dengan proses pembelajaran, maka peneliti memilih Penelitian Tindakan Kelas (PTK) dengan model Kemmis Mc. Taggart yang dilakukan dalam 3 siklus.
\end{abstract}

Kata Kunci : Sikap Peduli Lingkungan, Metode Tugas, Pembelajaran IPS 


\section{ABSTRACT \\ Improving Environmental Care Attitude of Students through Task Method in Learning Social Science. (Class Action Research in Junior High School of 3 Tanjungsari VIII Grade Class A)}

This research is motivated by the problems found by researcher at the time of initial observations on August, 12-15 2015, that is the lack of environmental care attitude of students. It is showed by some of the dimensions of the problems including low awareness of students to dispose a garbage, the accumulation of garbage, flower pot which is supposed to be a container for plant or flower just become polluted with litter, and the students do not watering a flower. The alternative problem solving done by giving the task of making the products by utilizing junk or trash that every day they consume (plastic garbage which has been used). Observing the issue examined related to the learning process, the researcher chose a Class Action Research with Kemmis Mc.Taggart model; it is done in three cycles.

Keywords: environmental care attitude of students, Task Method, Learning Social Science 


\section{A. PENDAhuluan}

Berdasarkan observasi awal peneliti di SMP Negeri 3 Tanjungsari kelas VIII A ditemukan lingkungan sekolah khususnya lingkungan kelas kurang baik seperti adanya sampah di dalam kelas, banyaknya sampah plastik, pot bunga yang seharusnya menjadi wadah tanaman saja menjadi tercemar dengan adanya sampah, dan tanaman yang ada di dalam kelas layu karena tidak di siram. Selain itu, penunjang media pembelajaran di SMP Negeri 3 Tanjungsari masih kurang seperti tidak adanya infokus di kelas. Keadaan seperti itu sangat disayangkan karena masih banyak siswa yang tidak peduli terhadap lingkungan sekitarnya. Kondisi seperti ini sangat mempengaruhi kenyamanan peserta didik di sekolah maupun di kelas dalam proses pembelajaran. Selain berpengaruh terhadap kenyamanan para peserta didik sampah dapat menimbulkan penyakit. Pada saat akan memulai pembelajaran keadaan kelas masih kotor sehingga harus membersihkan terlebih dahulu. Hal ini apabila terus dilakukan akan mengurangi waktu belajar.

Dengan melihat keadaan lingkungan sekolahnya terutama dikelas seperti itu, seharusnya siswa dapat memahami dan dapat menjaga lingkungannya. Karena apabila lingkungan kelasnya kotor akan berpengaruh terhadap kenyamanan siswa dalam belajar. Keadaan lingkungan yang tidak bersih merupakan salah satu penyebab terjadinya kerusakan lingkungan. Berdasarkan hasil wawancara kepada beberapa siswa mereka membuang sampah sembarangan sudah merupakan hal yang biasa dilakukan sekolah. Ada beberapa siswa berpendapat mereka membuang sampah sembarangan karena malas untuk pergi ke tempat sampah. Seperti pada saat berada dikelas mereka lebih baik membuangnya ke laci meja. Hal tersebut menunjukan bahwa siswa kurang memiliki sikap peduli lingkungan.

Manusia dan lingkungan merupakan satu kesatuan yang tidak dapat dipisahkan. Lingkungan memiliki peran penting dalam kehidupan manusia karena lingkungan menyediakan segala kebutuhan hidup manusia. Kebutuhan manusia tidak terbatas tetapi alam apabila terus-terusan di eksploitasi akan mengalami kerusakan atau tidak stabil. Oleh karena itu, perlu ditanamkan sikap dan nilai peduli lingkungan terhadap siswa dengan cara diberikannya kesempatan untuk mengidentifikasi masalah, memecahkan masalah, dan membuat solusi agar dapat mengurangi masalah lingkungan tersebut. Dapat dikatakan siswa SMP Negeri 3 Tanjungsari belum memiliki sikap peduli terhadap ligkungan karena masih banyak yang membuang sampah sembarangan, terdapat sampah botol plastik dan kertas di dalam kelas. Oleh karena itu, diperlukan suatu upaya untuk menumbuhkan sikap peduli lingkungan. Salah satunya yaitu melalui pembelajaran IPS yang diberikan di SMP yang berawal dari kepedulian terhadap lingkungan kelas dan sekolah, lalu diharapkan dapat memecahkan masalah yang ada di lingkungan masyarakat.

Banks (dalam Sapriya, 2008, hlm. 3) menyatakan bahwa social studies adalah bagian dari kurikulum sekolah dasar dan menengah yang mempunyai tanggung jawab pokok membantu para siswa untuk mengembangkan pengetahuan, keterampilan, sikap dan nilai yang diperlukan dalam hidup bernegara dalam lingkungan masyarakat. Dari pernyataan diatas terlihat bahwa pembelajaran IPS bukan hanya sebagai bagian dari kurikulum saja tetapi menuntut siswanya agar memiliki tanggung 
jawab, peka terhadap masalah-masalah sosial yang ada dalam lingkungannya serta dapat memberikan solusi terhadap permasalahan yang ada.

Pusat Kurikulum Kemendiknas (dalam Kusumah, 2014, hlm. 17) memaparkan bahwa peduli lingkungan merupakan sikap dan tindakan yang selalu berupaya mencegah kerusakan pada lingkungan alam di sekitarnya dan mengembangkan upaya-upaya untuk memperbaiki kerusakan alam yang sudah terjadi. Sikap peduli lingkungan yang harus dimiliki oleh siswa yaitu siswa tidak membuang sampah sembarangan dan melakukan pemilahan sampah organik dan anorganik. Siswa dapat menghemat kertas, diet kantung plastik dengan cara membawa tas yang go green dari rumah apabila belanja dan membawa botol minuman dari rumah. Juga sikap lainnya seperti menghemat energi dengan cara menggunakan listrik seperlunya dan menggunakan air seperlunya.

Goleman (2012, hlm. 10-11) merumuskan indikator mengenai kesadaran lingkungan diantaranya yaitu, mengembangkan empati terhadap segala bentuk kehidupan (developing empathy for all forms of life), mempraktikan keberlangsungan hidup sebagai tindakan kelompok mayarakat (embracing sustainability as a community practice), membuat sesuatu yang tidak terlihat menjadi terlihat (making the invisible visibel), mengantisipasi dampak tidak terduga (anticipating unintended consequences), dan memahami bagaimana kehidupan alam berlangsung (understanding how nature sustains life)

Dari lima indikator diatas, peneliti memfokuskan dua indikator yang akan diteliti. Indikator tersebut adalah mengembangkan empati terhadap segala bentuk kehidupan (Developing empathy for all forms of life) dan mengantisipasi dampak yang tidak terduga (Anticipating unintended consequences). Proses pembelajaran IPS di kelas guru hanya menekankan aspek kognitif saja. Seharusnya, guru dapat memberikan pembelajaran mencakup aspek kognitif, apektif, dan psikomotor. Oleh karena itu, salah satu upaya yang perlu dilakukan oleh guru IPS agar pembelajaran tidak hanya menekankan pada aspek kognitif saja. Guru IPS harus dapat memilih metode pembelajaran yang tepat dan dianggap mendukung proses pembelajaran IPS.

Untuk memperbaiki kondisi diatas peneliti bermaksud mengkaji lebih jauh bagaimana penerapan metode tugas untuk peningkatan sikap peduli lingkungan siswa. Guru memberikan pemahaman terhadap siswa bahwa sampah-sampah yang ada di sekitarnya dapat dimanfaatkan serta guru memberikan contoh dari pemanfaatan sampah tersebut. Sampah yang ada disekitar siswa dapat diolah menjadi media untuk mereka belajar. Dengan demikian sampah yang ada dapat berkurang sehingga tidak mencemari lingkungan dan menyebabkan penyakit. Pemberian tugas menurut Tibrani (dalam Elizaryati, 2011, hlm.10) merupakan salah satu cara penyajian bahan pelajaran dimana guru memberikan tugas agar siswa giat belajar. Menurut Sagala (dalam Pramanta, 2012, hlm. 4) metode pemberian tugas dan resitasi adalah cara penyajian bahan pelajaran di mana guru memberikan tugas tertentu agar murid melakukan kegiatan belajar kemudian harus dipertanggung jawabkannya, tugas yang diberikan dapat memperdalam bahan pelajaran, dan dapat pula mengecek bahan yang telah dipelajari. Selain untuk menjadikan siswa giat belajar tugas pembuatan media pembelajaran dari sampah bekas akan menjadikan pembelajaran IPS yang tidak hanya mencakup aspek kognitif saja melainkan mencakup aspek apektif dan 
psikomotor. Sagala (dalam Lestari, 2013, hlm. 5) mengemukakan salah satu tujuan metode pemberian tugas, yaitu tugas dapat lebih meyakinkan tentang apa yang dipelajari dari guru, lebih memperdalam, memperkaya dan memperluas wawasan tentang apa yang dipelajari.

Sesuai dengan uraian diatas, maka peneliti tertarik untuk melakukan Penelitian Tindakan Kelas dengan judul "Peningkatan Sikap Peduli Lingkungan Siswa Melalui Metode Tugas Dalam Pembelajaran IPS (Penelitian Tindakan Kelas di SMP Negeri 3 Tanjungsari Kelas VIII A)". Dengan rumusan masalah dalam penelitian yakni: Pertama, bagaimana guru merencanakan metode tugas untuk meningkatkan sikap peduli lingkungan siswa di SMP Negeri 3 Tanjungsari kelas VIII A? Kedua, Bagaimana guru melaksanakan metode tugas untuk meningkatkan sikap peduli lingkungan siswa di SMP Negeri 3 Tanjungsari kelas VIII A? Ketiga, Seberapa besar peningkatan sikap peduli lingkungan siswa melalui metode tugas di SMP Negeri 3 Tanjungsari kelas VIII A? Keempat, Bagaimana kendala dan solusi yang terjadi dalam penerapan metode tugas untuk meningkatkan sikap peduli lingkungan siswa di SMP Negeri 3 Tanjungsari kelas VIII A?

\section{B. METODE}

Penelitian dilakukan di SMP Negeri 3 Tanjungsari kelas VIII A. Hal ini didasarkan atas hasil observasi awal peneliti, dan juga hasil berdiskusi dengan guru mitra, yang dapat disimpulkan bahwa kelas VIII A kurang memiliki sikap peduli lingkungan. Adapun jumlah siswa dalam kelas tersebut adalah 22 orang yang terdiri 13 orang siswa laki-laki dan 9 orang siswa perempuan.

Penelitian ini menggunakan metode penelitian tindakan kelas (PTK) mengacu pada model Kemmis dan Taggart. Secara mendetail Kemmis dan Taggart (dalam Wiriaatmadja, 2012, hlm. 66) menjelaskan tahap-tahap penelitian tindakan yang dilakukannya. Pada tahap awal adalah perencanaan, kemudian pelaksanaan tindakan, pengamatan (observasi), dan yang terakhir adalah refleksi.

Penelitian ini menggunakan teknik pengumpulan data dan analisis data. Pada teknik pengumpulan data penelitian ini terdiri dari observasi, wawancara, studi dokumentasi, dan catatan lapangan. Selain itu, penelitian ini menggunakan instrumen yang terdiri dari lembar observasi aktivitas siswa, lembar wawancara siswa sebelum dan sesudah tindakan, lembar wawancara guru, serta catatan lapangan. Kemudian, dilakukan proses analisis data yang terdiri dari aktivitas; (1) Reduksi data yang berkolaborasi dengan guru mitra untuk memfokuskan permasalahan penelitian; (2) Display data yaitu penyajian data yang disusun secara singkat, padat, jelas dan komprehensif sehingga dapat memudahkan dalam memahami aspek yang diteliti; (3) Kesimpulan dan verifikasi merupakan kesimpulan sementara yang dapat berubah sesuai bukti-bukti di lapangan; (4) Validitas data merupakan ukuran tingkat kevalidan dan keshahihan suatu instrumen. Adapun bentuk validasi dalam penelitian tindakan kelas ini menggunakan member check yaitu dalam kegiatan ini peneliti menginformasikan penemuan yang diperoleh baik kepada guru maupun siswa pada setiap akhir kegiatan pembelajaran, audit trail dilakukan dengan cara mendiskusikan kebenaran data beserta prosedur pengumpulannya dengan guru untuk memperoleh data dengan validasi yang tinggi dan expert opinion yaitu dalam kegiatan ini peneliti 
mengkonsultasikan temuan-temuannya kepada pembimbing sehingga validasi data temuan yang dapat dipertanggung jawabkan kebenarannya.

\section{HASIL PENELITIAN DAN PEMBAHASAN}

Penelitian yang dilakukan pada bulan Agustus sampai September tahun ajaran 2015/2016 bertujuan untuk meningkatkan sikap peduli lingkungan siswa melalui metode tugas telah dilaksanakan dalam 3 siklus. Melalui proses tersebut hasil penelitian membuktikan bahwa sikap peduli lingkungan siswa dapat terlihat ketika pembelajaran IPS menggunakan media tugas dengan memanfaatkan barang bekas. Tabel di bawah ini, telah menunjukan hasil peningkatan sikap peduli lingkungan siswa dalam pembelajaran IPS terlihat dari siklus I,II dan III sebagai berikut :

\section{Gambar Diagram 4.16}

Aspek I mampu mengidentifikasi masalah-masalah yang terjadi pada lingkungan sekitar

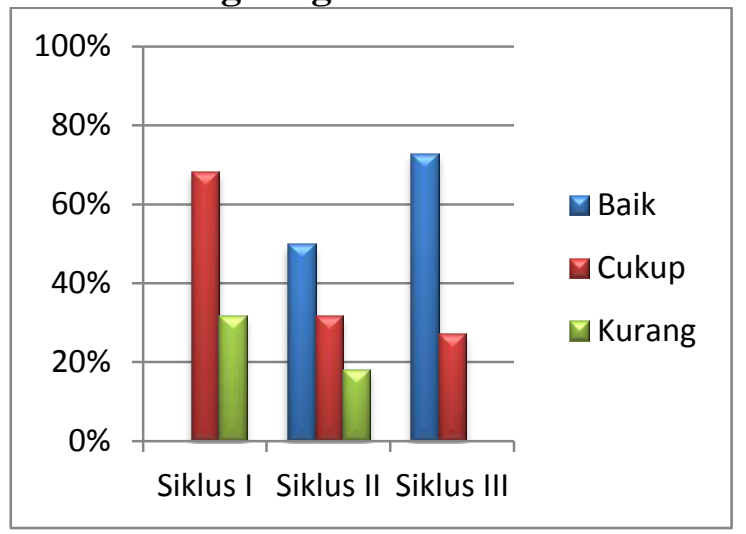

Sumber: Olah data peneliti tahun 2015

Berdasarkan diagram di atas dapat dilihat perbedaan peningkatan di setiap siklusnya. Pada siklus I aspek satu dapat terlihat siswa yang mendapat penilaian baik (B) sebanyak $0 \%$, atau dengan kata lain tidak ada siswa tergolong baik dalam mengidentifikasi masalah-masalah yang terjadi pada lingkungan sekitar. Adapun yang mendapat penilaian cukup (C) yaitu sebesar 68,2\% dan siswa yang mendapat penilaian kurang (K) sebanyak 31,8\%. Hal tersebut menunjukkan bahwa aspek satu ini masih jauh dari harapan penelitian.

Selanjutnya, pada siklus II sudah mengalami peningkatan yang cukup signifikan. Pada siklus II aspek satu dapat terlihat siswa yang mendapatkan penilaian baik (B) yaitu sebesar 50\%. Hal ini sudah membuktikan bahwa sebagian siswa sudah mampu mengidentifikasi masalah-masalah yang terjadi pada lingkungan sekitar dengan menyebutkan permasalahan lingkungan yang terjadi pada lingkungan sekitar dan memberikan contoh kasus. Siswa yang mendapatkan penilaian cukup (C) sebanyak $31,8 \%$ dan siswa yang mendapatkan penilaian kurang $(\mathrm{K})$ sebanyak $18,2 \%$.

Selanjutnya pada siklus III mengalami presentase yang paling tinggi dibandingkan siklus ke I dan ke II. Namun apabila dibandingkan dengan siklus II, rentang skor peningkatan tidak begitu besar, sehingga dengan kata lain peningkatan yang dialami pada siklus III, tidak begitu signifikan namun mencapai penilaian baik 
lebih dari 50\%. Adapun siswa yang mendapat penilaian baik (B) sebanyak 72,7\% hal ini membuktikan bahwa mayoritas siswa sudah mampu mengidentifikasi masalahmasalah yang terjadi pada lingkungan sekitar dengan menyebutkan permasalahan lingkungan yang terjadi pada lingkungan sekitar dan memberikan contoh kasus. Adapun beberapa siswa yang mendapat penilaian cukup (C) sebanyak 27,3\%, hal ini menunjukkan siswa mampu menyebutkan permasalahan lingkungan yang terjadi pada lingkungan sekitar. Sedangkan pada siklus III ini, siswa yang mendapat penilaian kurang (K) sebanyak 0\%. Sehingga mayoritas siswa sudah dikatakan berhasil dan memenuhi tujuan penelitian yaitu mampu mengidentifikasi masalah-masalah yang terjadi pada lingkungan sekitar.

Selanjutnya aspek ke dua yaitu mampu menjaga kebersihan lingkungan kelas. Secara keseluruhan aspek ini sudah ditunjukkan dalam aktifitas yang dilakukan oleh siswa serta dalam setiap siklusnya mengalami perkembangan yang meningkat. Agar lebih jelas dapat dilihat pada diagram di bawah ini:

\section{Gambar Diagram 4.17} Aspek II Mampu menjaga kebersihan lingkungan kelas

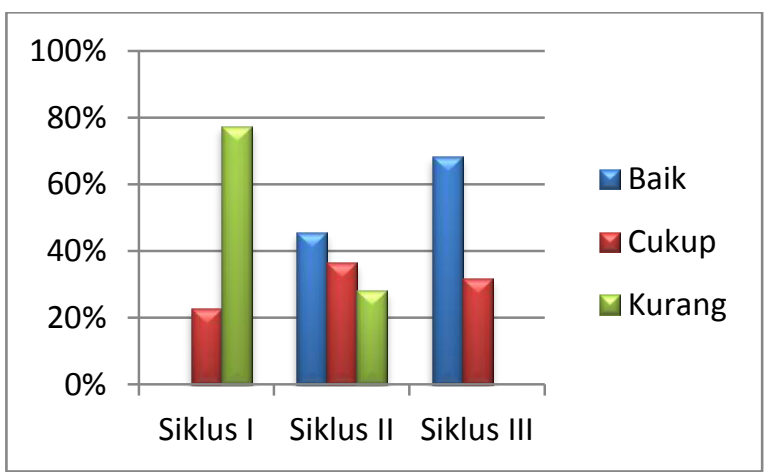

Sumber: Olah data peneliti tahun 2015

Berdasarkan diagram di atas dapat dilihat perbedaan peningkatan di setiap siklusnya. Pada siklus I aspek ke dua dapat terlihat siswa yang mendapat penilaian baik (B) sebanyak 0\%, atau dengan kata lain tidak ada siswa tergolong baik dalam menjaga kebersihan lingkungan kelas. Adapun yang mendapat penilaian cukup (C) yaitu sebesar $22,7 \%$ dan siswa yang mendapat penilaian kurang (K) sebanyak 77,3\%. Hal tersebut menunjukkan bahwaaspek ke dua ini masih jauh dari harapan penelitian.

Selanjutnya, pada siklus II sudah mengalami peningkatan yang cukup signifikan. Namun dapat dilihat pada diagram di atas kurang dari 50\% siswa di kelas yang mendapatkan penilaian baik (B) yaitu sebesar $45,5 \%$. Hal ini sudah membuktikan bahwa siswa belum mampu menjaga kebersihan lingkungan kelas dengan selalu melaksanakan piket harian atas dasar kesadaran sendiri. Siswa yang mendapatkan penilaian cukup (C) sebanyak 36,4\% dan siswa yang mendapatkan penilaian kurang (K) sebanyak $28,1 \%$.

Selanjutnya pada siklus III mengalami presentase yang paling tinggi dibandingkan siklus ke I dan ke II. Namun apabila dibandingkan dengan siklus II, rentang skor peningkatan tidak begitu besar, sehingga dengan kata lain peningkatan yang dialami pada siklus III, tidak begitu signifikan namun mencapai penilaian baik 
lebih dari 50\%. Adapun siswa yang mendapat penilaian baik (B) sebanyak 68,2\% hal ini membuktikan bahwa mayoritas siswa sudah mampu menjaga kebersihan lingkungan kelas dengan selalu melaksanakan piket harian atas dasar kesadaran sendiri. Adapun beberapa siswa yang mendapat penilaian cukup (C) sebanyak 31,8\%, hal ini menunjukkan siswa mampu menjaga kebersihan lingkungan (kelas) dengan harus di ingatkan kembali untuk melaksanakan piket harian. Sedangkan pada siklus III ini, siswa yang mendapat penilaian kurang (K) sebanyak 0\%. Sehingga mayoritas siswa sudah dikatakan berhasil dan memenuhi tujuan penelitian yaitu mampu menjaga kebersihan lingkungan kelas.

Selanjutnya aspek tiga yaitu berani menegur teman yang membuang sampah sembarangan. Secara keseluruhan aspek ini sudah ditunjukkan dalam aktifitas yang dilakukan oleh siswa serta dalam setiap siklusnya mengalami perkembangan yang meningkat. Agar lebih jelas dapat dilihat pada diagram di bawah ini:

\section{Gambar Diagram 4.18}

\section{Aspek III Membuang sampah kedalam tempat sampah}

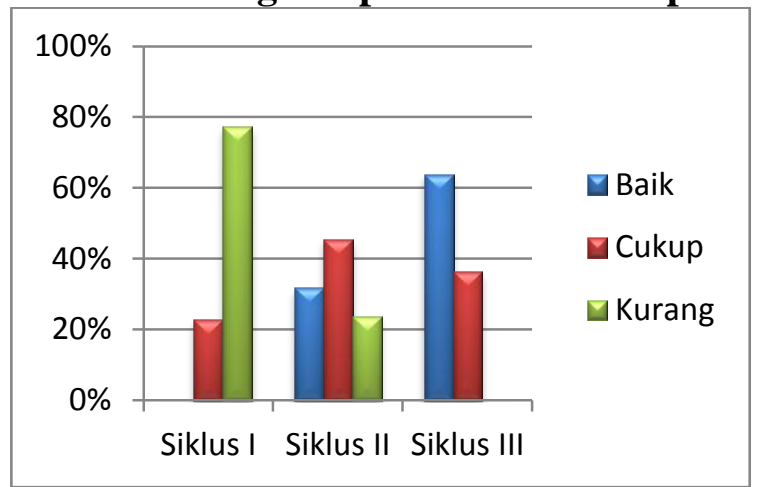

Sumber: Olah data peneliti tahun 2015

Berdasarkan diagram di atas dapat dilihat perbedaan peningkatan di setiap siklusnya. Pada siklus I aspek ke tiga dapat terlihat siswa yang mendapat penilaian baik (B) sebanyak 0\%, atau dengan kata lain tidak ada siswa tergolong baik dalam membuang sampah kedalam tempat sampah. Adapun yang mendapat penilaian cukup (C) yaitu sebesar 18,2\% dan siswa yang mendapat penilaian kurang (K) sebanyak $81,8 \%$. Hal tersebut menunjukkan bahwa aspek ke tiga ini masih jauh dari harapan penelitian.

Selanjutnya, pada siklus II sudah mengalami peningkatan yang sangat signifikan. Dapat dilihat pada diagram di atas 50\% siswa di kelas yang mendapatkan penilaian baik (B). Hal ini sudah membuktikan bahwa siswa sudah terbiasa membuang sampah ke dalam tempat sampah atas dasar kesadaran sendiri. Siswa yang mendapatkan penilaian cukup (C) sebanyak 31,8\% dan siswa yang mendapatkan penilaian kurang (K) sebanyak $18,2 \%$.

Selanjutnya pada siklus III mengalami presentase yang paling tinggi dibandingkan siklus ke I dan ke II. Namun apabila dibandingkan dengan siklus II, rentang skor peningkatan tidak begitu besar, sehingga dengan kata lain peningkatan yang dialami pada siklus III tidak begitu signifikan namun mencapai penilaian baik lebih dari 50\%. Adapun siswa yang mendapat penilaian baik (B) sebanyak 63,6\% hal 
ini membuktikan bahwa mayoritas siswa sudah terbiasa membuang sampah kedalam tempat sampah atas kesadaran sendiri. Adapun beberapa siswa yang mendapat penilaian cukup (C) sebanyak 36,4\%, hal ini menunjukkan siswa membuang sampah kedalam tempat sampah harus selalu di ingatkan. Sedangkan pada siklus III ini, siswa yang mendapat penilaian kurang (K) sebanyak 0\%. Sehingga mayoritas siswa sudah dikatakan berhasil dan memenuhi tujuan penelitian yaitu mampu membuang sampah kedalam tempat sampah.

Selanjutnya aspek ke empat yaitu berani menegur teman yang membuang sampah sembarangan. Secara keseluruhan aspek ini sudah ditunjukkan dalam aktifitas yang dilakukan oleh siswa serta dalam setiap siklusnya mengalami perkembangan yang meningkat. Agar lebih jelas dapat dilihat pada diagram di bawah ini:

Gambar Diagram 4.19

Aspek IV Berani menegur teman yang membuang sampah sembarangan

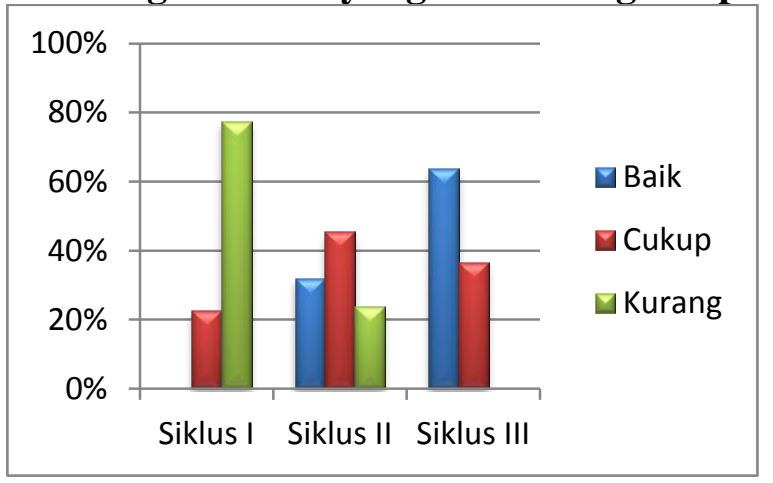

Sumber: Olah data peneliti tahun 2015

Berdasarkan diagram di atas dapat dilihat perbedaan peningkatan di setiap siklusnya. Pada siklus I aspek ke empat dapat terlihat siswa yang mendapat penilaian baik (B) sebanyak 0\%, atau dengan kata lain tidak ada siswa tergolong baik berani menegur teman yang membuang sampah sembarangan. Adapun yang mendapat penilaian cukup (C) yaitu sebesar 22,7\% dan siswa yang mendapat penilaian kurang (K) sebanyak 77,3\%. Hal tersebut menunjukkan bahwa aspek III ini masih jauh dari harapan penelitian.

Selanjutnya, pada siklus II sudah mengalami peningkatan yang cukup signifikan. Namun dapat dilihat pada diagram di atas kurang dari $50 \%$ siswa di kelas yang mendapatkan penilaian baik (B) yaitu sebesar 31,8\%. Hal ini sudah membuktikan bahwa siswa sudah berani berani menegur teman yang membuang sampah sembarangan dengan kata-kata yang sopan. Siswa yang mendapatkan penilaian cukup (C) sebanyak 45,5\% dan siswa yang mendapatkan penilaian kurang (K) sebanyak 23,7\%.

Selanjutnya pada siklus III mengalami presentase yang paling tinggi dibandingkan siklus ke I dan ke II. Namun apabila dibandingkan dengan siklus II, rentang skor peningkatan tidak begitu besar, sehingga dengan kata lain peningkatan yang dialami pada siklus III tidak begitu signifikan namun mencapai penilaian baik lebih dari 50\%. Adapun siswa yang mendapat penilaian baik (B) sebanyak 63,6\% hal ini membuktikan bahwa mayoritas Siswa berani menegur teman yang membuang sampah sembarangan dengan kata-kata yang sopan. Adapun beberapa siswa yang mendapat 
penilaian cukup (C) sebanyak 36,4\%, hal ini menunjukkan Siswa berani menegur teman yang membuang sampah sembarangan dengan kata-kata yang tidak sopan. Sedangkan pada siklus III ini, siswa yang mendapat penilaian kurang (K) sebanyak 0\%. Sehingga mayoritas siswa sudah dikatakan berhasil dan memenuhi tujuan penelitian yaitu berani menegur teman yang membuang sampah sembarangan.

Selanjutnya aspek ke lima yaitu mampu mengajak orang lain untuk selalu menjaga lingkungan. Secara keseluruhan aspek ini sudah ditunjukkan dalam aktifitas yang dilakukan oleh siswa serta dalam setiap siklusnya mengalami perkembangan yang meningkat. Agar lebih jelas dapat dilihat pada diagram di bawah ini:

\section{Gambar Diagram 4.20}

Aspek V mampu mengajak orang lain untuk selalu menjaga lingkungan

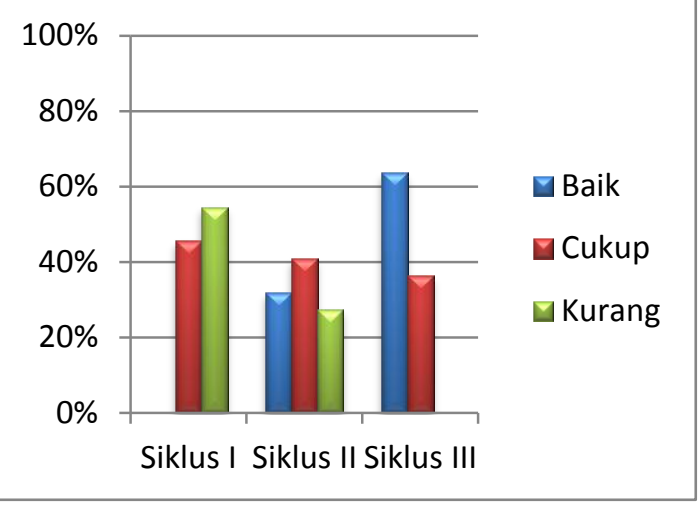

Sumber: Olah data peneliti tahun 2015

Berdasarkan diagram di atas dapat dilihat perbedaan peningkatan di setiap siklusnya. Pada siklus I aspek ke lima dapat terlihat siswa yang mendapat penilaian baik (B) sebanyak 0\%, atau dengan kata lain tidak ada siswa tergolong baik mengajak orang lain untuk selalu menjaga lingkungan. Adapun yang mendapat penilaian cukup (C) yaitu sebesar 45,5\% dan siswa yang mendapat penilaian kurang (K) sebanyak $54,53 \%$. Hal tersebut menunjukkan bahwa aspek ke lima ini masih jauh dari harapan penelitian.

Selanjutnya, pada siklus II sudah mengalami peningkatan yang cukup signifikan. Namun dapat dilihat pada diagram di atas kurang dari $50 \%$ siswa di kelas yang mendapatkan penilaian baik (B) yaitu sebesar 31,8\%. Hal ini sudah membuktikan bahwa siswa sudah mengajak orang lain untuk selalu menjaga lingkungan dengan menggunakan kata-kata sopan. Siswa yang mendapatkan penilaian cukup (C) sebanyak 40,9\% dan siswa yang mendapatkan penilaian kurang (K) sebanyak 27,3\%.

Selanjutnya pada siklus III mengalami presentase yang paling tinggi dibandingkan siklus ke I dan ke II. Apabila dibandingkan dengan siklus II, rentang skor peningkatan sama, namun yang mencapai penilaian baik lebih dari 50\%. Adapun siswa yang mendapat penilaian baik (B) sebanyak 63,6\% hal ini membuktikan bahwa mayoritas siswa mampu mengajak orang lain untuk selalu menjaga lingkungan dengan menggunakan kata-kata sopan. Adapun beberapa siswa yang mendapat penilaian cukup (C) sebanyak 36,4\%, hal ini menunjukkan mengajak orang lain untuk selalu menjaga lingkungan dengan menggunakan kata-kata tidak sopan. Sedangkan 
pada siklus III ini, siswa yang mendapat penilaian kurang $(\mathrm{K})$ sebanyak 0\%. Sehingga mayoritas siswa sudah dikatakan berhasil dan memenuhi tujuan penelitian yaitu mampu mengajak orang lain untuk selalu menjaga lingkungan.

Selanjutnya aspek ke enam yaitu memelihara tanaman yang ada di kelas . Secara keseluruhan aspek ini sudah ditunjukkan dalam aktifitas yang dilakukan oleh siswa serta dalam setiap siklusnya mengalami perkembangan yang meningkat. Agar lebih jelas dapat dilihat pada diagram di bawah ini:

Gambar Diagram 4.21

Aspek VI Memelihara tanaman yang ada di kelas

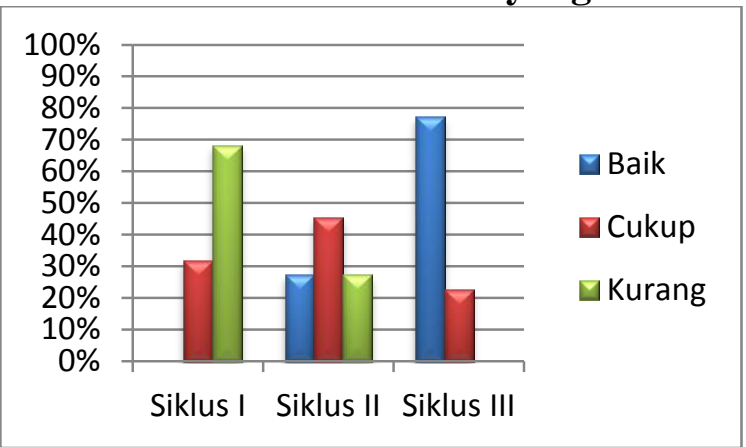

Sumber: Olah data peneliti tahun 2015

Berdasarkan diagram di atas dapat dilihat perbedaan peningkatan di setiap siklusnya. Pada siklus I aspek ke tujuh dapat terlihat siswa yang mendapat penilaian baik (B) sebanyak 0\%, atau dengan kata lain tidak ada siswa tergolong baik dalam mengelompokan sampah organik dan anorganik. Adapun yang mendapat penilaian cukup (C) yaitu sebesar 18,2\% dan siswa yang mendapat penilaian kurang (K) sebanyak $81,8 \%$. Hal tersebut menunjukkan bahwa aspek ke tujuh ini masih jauh dari harapan penelitian.

Selanjutnya, pada siklus II sudah mengalami peningkatan dari siklus I. Dapat dilihat pada diagram di atas siswa yang mendapatkan penilaian baik (B) sebanyak 27,3\%. Siswa yang mendapatkan penilaian cukup (C) sebanyak 45,5\% dan siswa yang mendapatkan penilaian kurang $(\mathrm{K})$ sebanyak $27,3 \%$.

Selanjutnya pada siklus III mengalami presentase yang paling tinggi dibandingkan siklus ke I dan ke II. Apabila dibandingkan dengan siklus II, peningkatan dalam siklus III ini sangat signifikan, yang mencapai penilaian baik lebih dari $50 \%$. Adapun siswa yang mendapat penilaian baik (B) sebanyak $77,3 \%$ hal ini membuktikan bahwa mayoritas siswa sudah terbiasa menyiram tanaman tanpa adanya paksaan. Adapun beberapa siswa yang mendapat penilaian cukup (C) sebanyak $22,7 \%$ hal ini menunjukkan siswa menyiram tanaman karena di suruh. Sedangkan pada siklus III ini, siswa yang mendapat penilaian kurang (K) sebanyak 0\%. Sehingga mayoritas siswa sudah dikatakan berhasil dan memenuhi tujuan penelitian yaitu memelihara tanaman yang ada di kelas.

Selanjutnya aspek ke tujuh yaitu mampu mengelompokan sampah organik dan anorganik. Secara keseluruhan aspek ini sudah ditunjukkan dalam aktifitas yang dilakukan oleh siswa serta dalam setiap siklusnya mengalami perkembangan yang meningkat. Agar lebih jelas dapat dilihat pada diagram di bawah ini: 
Gambar Diagram 4.22

\section{Aspek VII Mampu mengelompokan sampah organik dan anorganik}

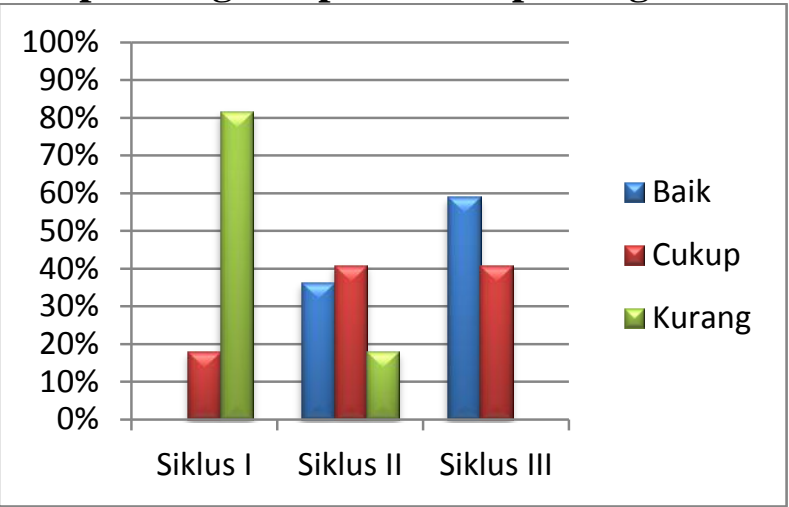

Sumber: Olah data peneliti tahun 2015

Berdasarkan diagram di atas dapat dilihat perbedaan peningkatan di setiap siklusnya. Pada siklus I aspek ke tujuh dapat terlihat siswa yang mendapat penilaian baik (B) sebanyak 0\%, atau dengan kata lain tidak ada siswa tergolong mampu mengelompokan sampah organik dan anorganik dengan membuang sampah berdasarkan pengelompokan sampah organic dan anorganik. Adapun yang mendapat penilaian cukup (C) yaitu sebesar 18,2\% dan siswa yang mendapat penilaian kurang (K) sebanyak $81,8 \%$. Hal tersebut menunjukkan bahwa aspek ke tujuh ini masih jauh dari harapan penelitian.

Selanjutnya, pada siklus II sudah mengalami peningkatan yang cukup signifikan. Namun dapat dilihat pada diagram di atas kurang dari 50\% siswa di kelas yang mendapatkan penilaian baik (B) yaitu sebesar 36,4\%. Hal ini sudah membuktikan bahwa siswa sudah mampu mengelompokan sampah organik dan anorganik dengan membuang sampah berdasarkan pengelompokan sampah organic dan anorganik. Siswa yang mendapatkan penilaian cukup (C) sebanyak 40,9\% dan siswa yang mendapatkan penilaian kurang (K) sebanyak 18,2\%.

Selanjutnya pada siklus III mengalami presentase yang paling tinggi dibandingkan siklus ke I dan ke II. Apabila dibandingkan dengan siklus II, rentang skor peningkatan sama, namun yang mencapai penilaian baik lebih dari 50\%. Adapun siswa yang mendapat penilaian baik (B) sebanyak 59,1\% hal ini membuktikan bahwa mayoritas siswa mampu mengelompokan sampah organik dan anorganik dengan membuang sampah berdasarkan pengelompokan sampah organic dan anorganik. Adapun beberapa siswa yang mendapat penilaian cukup (C) sebanyak 40,9\%, hal ini menunjukkan siswa mampu mengelompokan sampah organik dan anorganik tetapi membuang sampah tidak berdasarkan pengelompokan sampah organic dan anorganik. Sedangkan pada siklus III ini, siswa yang mendapat penilaian kurang (K) sebanyak 0\%. Sehingga mayoritas siswa sudah dikatakan berhasil dan memenuhi tujuan penelitian yaitu mampu mengelompokan sampah organik dan anorganik.

Selanjutnya aspek ke delapan yaitu mampu memanfaatkan barang bekas menjadi barang yang lebih berguna. Secara keseluruhan aspek ini sudah ditunjukkan dalam 
aktifitas yang dilakukan oleh siswa serta dalam setiap siklusnya mengalami perkembangan yang meningkat. Agar lebih jelas dapat dilihat pada diagram di bawah ini:

\section{Gambar Diagram 4.23 \\ Aspek VIII Mampu memanfaatkan barang-barang bekas menjadi barang} yang lebih berguna

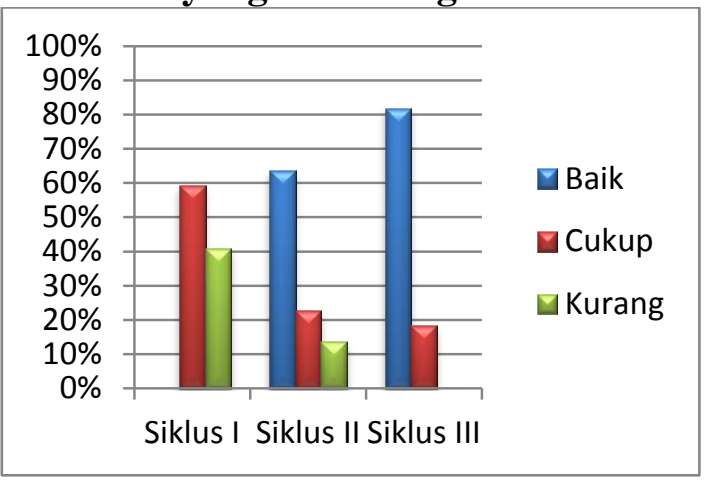

Sumber: Olah data peneliti tahun 2015

Berdasarkan diagram di atas dapat dilihat perbedaan peningkatan di setiap siklusnya. Pada siklus I aspek ke delapan dapat terlihat siswa yang mendapat penilaian baik (B) sebanyak 0\%, atau dengan kata lain tidak ada siswa tergolong baik dalam memanfaatkan barang-barang bekas atau sampah untuk membuat tugas produk. Adapun yang mendapat penilaian cukup (C) yaitu sebesar 59,1\% dan siswa yang mendapat penilaian kurang $(\mathrm{K})$ sebanyak $59,1 \%$. Hal tersebut menunjukkan bahwa aspek delapan ini sudah cukup baik.

Selanjutnya, pada siklus II sudah mengalami peningkatan yang sangat signifikan. Dapat dilihat pada diagram di atas siswa di kelas yang mendapatkan penilaian baik (B) yaitu sebesar 63,6\%. Hal ini sudah membuktikan bahwa siswa mampu memanfaatkan barang bekas menjadi barang yang lebih berguna serta mengetahui manfaat penggunaan pemanfaatan barang bekas. Siswa yang mendapatkan penilaian cukup (C) sebanyak 22,7\% dan siswa yang mendapatkan penilaian kurang (K) sebanyak $13,6 \%$.

Selanjutnya pada siklus III mengalami presentase yang paling tinggi dibandingkan siklus ke I dan ke II. Namun apabila dibandingkan dengan siklus II, rentang skor peningkatan tidak begitu besar, sehingga dengan kata lain peningkatan yang dialami pada siklus III tidak begitu signifikan namun mencapai penilaian baik lebih dari 50\%. Adapun siswa yang mendapat penilaian baik (B) sebanyak 81,8\% hal ini membuktikan bahwa mayoritas siswa mampu memanfaatkan barang bekas menjadi barang yang lebih berguna serta mengetahui manfaat penggunaan pemanfaatan barang bekas. Adapun beberapa siswa yang mendapat penilaian cukup (C) sebanyak $18,2 \%$ hal ini menunjukkan siswa hanya sebagian mampu memanfaatkan barang bekas menjadi barang yang lebih berguna namun tidak mengetahui manfaat penggunaan pemanfaatan barang bekas. Sedangkan pada siklus III ini, siswa yang mendapat penilaian kurang (K) sebanyak 0\%. Sehingga mayoritas siswa sudah dikatakan berhasil dan memenuhi tujuan penelitian yaitu dapat memanfaatkan barang-barang bekas menjadi barang yang lebih berguna. 
Selanjutnya aspek $\mathrm{V}$ yaitu tidak meninggalkan sampah setelah mengerjakan tugas di dalam kelas. Secara keseluruhan aspek ini sudah ditunjukkan dalam aktifitas yang dilakukan oleh siswa serta dalam setiap siklusnya mengalami perkembangan yang meningkat. Agar lebih jelas dapat dilihat pada diagram di bawah ini:

\section{Gambar Diagram 4.24}

Aspek IX Tidak terdapat sampah setelah mengerjakan tugas di dalam kelas

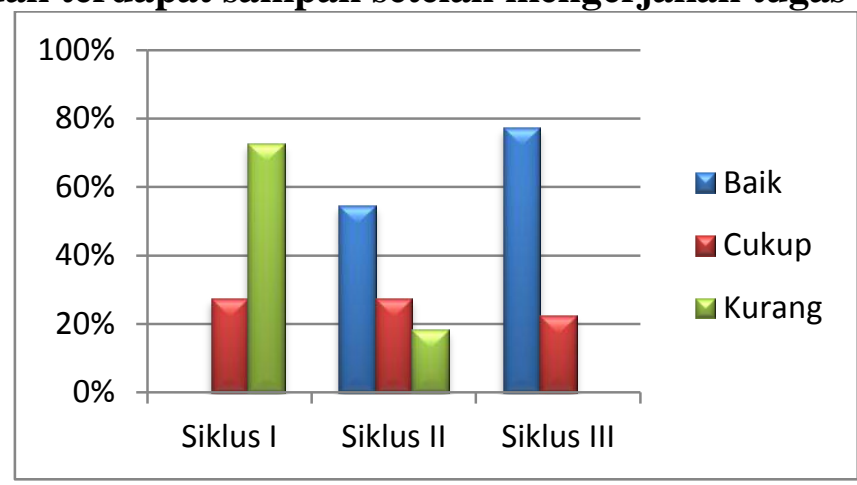

Sumber: Olah data peneliti tahun 2015

Berdasarkan diagram di atas dapat dilihat perbedaan peningkatan di setiap siklusnya. Pada siklus I aspek sembilan dapat terlihat siswa yang mendapat penilaian baik (B) sebanyak 0\%, atau dengan kata lain tidak ada siswa tergolong baik dalam tidak terdapat sampah setelah mengerjakan tugas di dalam kelas. Adapun yang mendapat penilaian cukup (C) yaitu sebesar $27,3 \%$ dan siswa yang mendapat penilaian kurang $(\mathrm{K})$ sebanyak $72,7 \%$. Hal tersebut menunjukkan bahwa aspek sembilan ini masih jauh dari harapan penelitian.

Selanjutnya, pada siklus II sudah mengalami peningkatan yang sangat signifikan. Dapat dilihat pada diagram di atas 50\% siswa di kelas yang mendapatkan penilaian baik (B) yaitu sebesar 54,5\%. Hal ini sudah membuktikan bahwa tidak meninggalkan sampah setelah mengerjakan tugas di dalam kelas. Siswa yang mendapatkan penilaian cukup (C) sebanyak 27,3\% dan siswa yang mendapatkan penilaian kurang (K) sebanyak $18,2 \%$.

Selanjutnya pada siklus III mengalami presentase yang paling tinggi dibandingkan siklus ke I dan ke II. Namun apabila dibandingkan dengan siklus II, rentang skor peningkatan tidak begitu besar, sehingga dengan kata lain peningkatan yang dialami pada siklus III tidak begitu signifikan namun mencapai penilaian baik lebih dari 50\%. Adapun siswa yang mendapat penilaian baik (B) sebanyak 77,3\% hal ini membuktikan bahwa mayoritas siswa sudah terbiasa membuang sampah sisa mengerjakan tugasnya kedalam tempat sampah sehingga setelah mengerjakan tugas tidak meninggalkan sampah. Adapun beberapa siswa yang mendapat penilaian cukup (C) sebanyak $22,3 \%$ hal ini menunjukkan siswa hanya sebagian kecil siswa yang meninggalkan sampah setelah mengerjakan tugas. Sedangkan pada siklus III ini, siswa yang mendapat penilaian kurang $(\mathrm{K})$ sebanyak $0 \%$. Sehingga mayoritas siswa sudah dikatakan berhasil dan memenuhi tujuan penelitian yaitu tidak meninggalkan sampah setelah mengerjakan tugas di dalam kelas.

Selanjutnya aspek ke sepuluh yaitu tidak mampu mengurangi penggunaan plastik. Secara keseluruhan aspek ini sudah ditunjukkan dalam aktifitas yang 
dilakukan oleh siswa serta dalam setiap siklusnya mengalami perkembangan yang meningkat. Agar lebih jelas dapat dilihat pada diagram di bawah ini:

\section{Gambar Diagram 4.25}

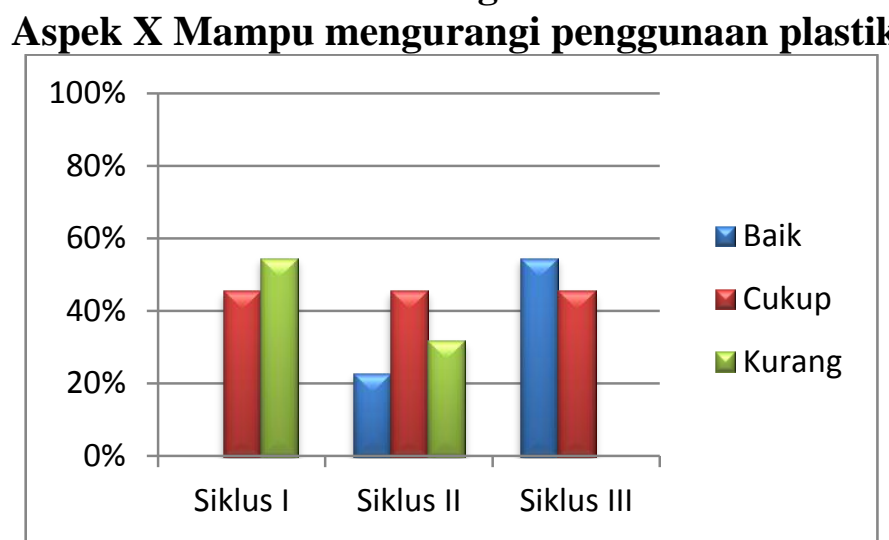

Sumber: Olah data peneliti tahun 2015

Berdasarkan diagram di atas dapat dilihat perbedaan peningkatan di setiap siklusnya. Pada siklus I aspek ke sepuluh dapat terlihat siswa yang mendapat penilaian baik (B) sebanyak $0 \%$, atau dengan kata lain tidak ada siswa tergolong baik dalam mengurangi penggunaan plastik. Adapun yang mendapat penilaian cukup (C) yaitu sebesar 45,4\% dan siswa yang mendapat penilaian kurang (K) sebanyak 54,5\%. Hal tersebut menunjukkan bahwa aspek sepuluh ini masih jauh dari harapan penelitian.

Selanjutnya, pada siklus II sudah mengalami peningkatan dari siklus I. Dapat dilihat pada diagram di atas siswa yang mendapatkan penilaian baik (B) sebanyak $22,7 \%$. Siswa yang mendapatkan penilaian cukup (C) sebanyak $45,5 \%$ dan siswa yang mendapatkan penilaian kurang (K) sebanyak 31,8\%.

Selanjutnya pada siklus III mengalami presentase yang paling tinggi dibandingkan siklus ke I dan ke II. Apabila dibandingkan dengan siklus II, peningkatan dalam siklus III ini sangat signifikan, yang mencapai penilaian baik lebih dari $50 \%$. Adapun siswa yang mendapat penilaian baik (B) sebanyak 54,5\% hal ini membuktikan bahwa mayoritas siswa sudah mampu mengurangi penggunaan plastik dengan membawa botol minum dari rumah tanpa harus di suruh. Adapun beberapa siswa yang mendapat penilaian cukup (C) sebanyak 45,5\% hal ini menunjukkan siswa menyiram tanaman karena di suruh. Sedangkan pada siklus III ini, siswa yang mendapat penilaian kurang $(\mathrm{K})$ sebanyak 0\%. Sehingga mayoritas siswa sudah dikatakan berhasil dan memenuhi tujuan penelitian yaitu mengurangi penggunaan plastik.

Selanjutnya aspek ke sebelas yaitu mampu memberikan solusi terhadap permasalahan yang terjadi pada lingkungan sekitar. Secara keseluruhan aspek ini sudah ditunjukkan dalam aktifitas yang dilakukan oleh siswa serta dalam setiap siklusnya mengalami perkembangan yang meningkat. Agar lebih jelas dapat dilihat pada diagram di bawah ini: 


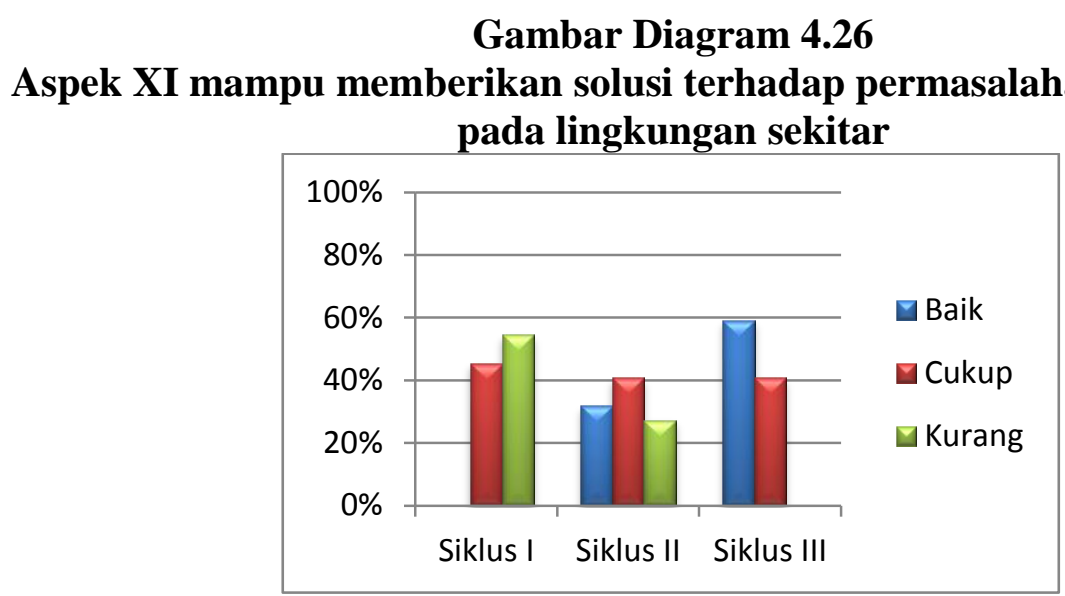

Sumber: Olah data peneliti tahun 2015

Berdasarkan diagram di atas dapat dilihat perbedaan peningkatan di setiap siklusnya. Pada siklus I aspek sebelas dapat terlihat siswa yang mendapat penilaian baik (B) sebanyak 0\%, atau dengan kata lain tidak ada siswa tergolong baik dalam memberikan solusi terhadap permasalahan yang terjadi pada lingkungan sekitar. Adapun yang mendapat penilaian cukup (C) yaitu sebesar 45,5\% dan siswa yang mendapat penilaian kurang $(\mathrm{K})$ sebanyak $54,5 \%$. Hal tersebut menunjukkan bahwa aspek sebelas ini masih jauh dari harapan penelitian.

Selanjutnya, pada siklus II sudah mengalami peningkatan yang sangat signifikan. Dapat dilihat pada diagram di atas yang mendapatkan penilaian baik (B) yaitu sebesar 31,8\%. Hal ini sudah membuktikan bahwa siswa dapat memberikan solusi yang relevan terhadap permasalahan yang terjadi pada lingkungan sekitar serta diaplikasikan dalam kehidupan sehari-hari. Siswa yang mendapatkan penilaian cukup (C) sebanyak 40,9\% dan siswa yang mendapatkan penilaian kurang (K) sebanyak $27,3 \%$.

Selanjutnya pada siklus III mengalami presentase yang paling tinggi dibandingkan siklus ke I dan ke II. Namun apabila dibandingkan dengan siklus II, rentang skor peningkatan tidak begitu besar, sehingga dengan kata lain peningkatan yang dialami pada siklus III tidak begitu signifikan namun mencapai penilaian baik lebih dari 50\%. Adapun siswa yang mendapat penilaian baik (B) sebanyak 59,1\% hal ini membuktikan bahwa mayoritas siswa sudah dapat memberikan solusi yang relevan terhadap permasalahan yang terjadi pada lingkungan sekitar serta diaplikasikan dalam kehidupan sehari-hari. Adapun beberapa siswa yang mendapat penilaian cukup (C) sebanyak 40,9\% hal ini menunjukkan dapat memberikan solusi yang relevan terhadap permasalahan yang terjadi pada lingkungan sekitar namun tidak diaplikasikan dalam kehidupan sehari-hari. Sedangkan pada siklus III ini, siswa yang mendapat penilaian kurang (K) sebanyak 0\%. Sehingga mayoritas siswa sudah dikatakan berhasil dan memenuhi tujuan penelitian mampu memberikan solusi terhadap permasalahan yang terjadi pada lingkungan sekitar 


\section{KESIMPULAN}

Berdasarkan hasil penelitian tindakan kelas yang telah dilaksanakan di kelas VIII A SMP Negeri 3 Tanjungsari dalam rangka meningkatkan sikap peduli lingkungan siswa dalam pembelajaran IPS melalui metode tugas dapat ditarik kesimpulan sebagai berikut: Pertama, Perencanaan dalam penelitian ini berangkat dari observasi awal penelitian dimana peneliti menemukan adanya permasalahan pada peserta didik kelas VIII A yaitu kurangnya kesadaran siswa dalam hal menjaga lingkungan kelas, mengelola sampah, serta kurangnya pengembangan tugas yang bermakna bagi siswa, guru hanya menekankan aspek kognitif saja. Hal itu terlihat dari keadaan kelas yang kotor banyak sampah berserakan di dalam kelas. Tanaman yang ada dalam kelas tidak terawat tanaman tersebut terlihat layu. Selain itu juga terlihat pada jam istirahat siswa membawa makanan kedalam kelas dan membuang sampah makanan tersebut kedalam laci meja. Berdasarkan permasalahan tersebut, maka perencanaan disusun dengan mengupayakan metode tugas dapat meningkatkan sikap peduli lingkungan siswa. Perencanaan-perencanaan tersebut mencakup kegiatan mempersiapkan RRP, media pembelajaran serta mempersiapkan instrumen penelitian berupa pedoman observasi, catatan lapangan dan pedoman wawancara yang dibuat berdasarkan indikator-indikator yang telah ditentukan. Peneliti merencanakan setiap siklus memberikan tugas produk dengan memanfaatkan barang-barang bekas dan selalu memotivasi siswa agar menjaga lingkungannya. Kegiatan dalam pembelajaran disajikan dengan menghubungkan materi pembelajaran dengan kehidupan sehari-hari siswa.

Kedua, Penelitian dilaksanakan di kelas VIII A SMP Negeri 3 Tanjungsari yang dilakukan pada bulan Agustus sampai September tahun ajaran 2015/2016 bertujuan untuk meningkatkan sikap peduli lingkungan siswa. Penelitian ini dilaksanakan sebanyak tiga siklus. Pada siklus I keadaan kelas masih kotor, banyak siswa yang membuang sampah sembarangan. Siswa sudah mengetahui permasalah lingkungan dan cara mengatasinya, namun siswa belum menerapkan dala kehidupannya. Pada siklus ini siswa diberi tugas untuk membuat miniatur tentang kepadatan penduduk. Dalam pembuatan miniatur ini siswa masih kebingungan untuk menggunakan barang bekas sehingga siswa menggunakan barang yang baru. Pada siklus II siswa diminta untuk membuat tugas piramida penduduk. Pada siklus ini siswa sudah mulai terbiasa memanfaatkan barang bekas terlihat dari sebagian besar siswa sudah menggunakan barang bekas. Saat mengerjakan tugas piramida penduduk itu banyak sampah berserakan namun sebagian siswa membuangnya kedalam tepat sampah. Pada siklus III siswa diminta untuk membuat poster mengenai kerusakan lingkungan dan cara pencegahannya. dalam pembuatan poster juga siswa sudah terbiasa memanfaatkan barang bekas. Dalam proses membuat poster siswa tidak meninggalkan sampah, siswa tanpa di ingatkan sudah membuang sampah sisa membuat poster tersebut kedalam tempat sampah.

Ketiga, Pemberian metode tugas berpengaruh terhadap sikap peduli lingkungan siswa di kelas VIII A SMP Negeri 3 Tanjungsari. Sikap peduli lingkungan siswa mengalami peningkatan dari setiap siklusnya. Hal ini terlihat pada siklus I keadaan kelas masih kotor, banyak sampah berserakan. Tanaman yang ada dikelas tidak terawat bahkan terdapat sampah pada pot bunga. Pada jam istirahat sebagian besar 
siswa membuang sampah sembarangan dan membuang kedalam laci meja. Selanjutnya pada siklus II ini sudah terlihat ada peningkatan yang signifakan dari siklus I. Hal ini terlihat dari kelas yang bersih karena pada jam pelajaran dimulai siswa melaksanakan piket harian terlebih dahulu dan siswa pun menyiram tanaman yang ada dikelasnya. Saat mengerjakan tugas pun siswa sudah ada peningkatan dimana siswa sudah mau membuang sampah sisa-sisa barang bekas kedalam tempat sampah. Pada jam istirahat pun siswa sudah mulai terlihat peningkatan dimana siswa membuang sampah bekas makanannya dibuang kedalam tempat sampah dan sudah berani menegur teman yang membuang sampah sembarangan. Kemudian pada siklus III menunjukkan adanya peningkatan yang cukup besar terlihat pada semua aspek tidak ada yang mencapai nilai kurang (K) dibandingkan dengan siklus I dan II. Hal ini terlihat pada saat siswa masuk kedalam kelas keadaan kelas sudah bersih dan terdapat bendera putih. Bendera putih menandakan kelas yang paling bersih di SMP Negeri 3 Tanjungsari. Selain itu, siswa juga sudah peka terhadap permasalahan lingkungan dan mengetahui cara mengatasinya serta sudah diterapkan dalam kehidupan sehari-harinya. Seperti dalam meja guru terdapat bunga dimana bunga tersebut hasil karya siswa dengan cara mendaur ulang sampah plastik menjadi bunga. Kemudian pada saat jam istirahat juga sudah ada peningkatan sebagian besar siswa sudah membuang sampah makanan kedalam tempat sampah. Namun demikian guru tetap membimbing dan memotivasi siswa untuk senantiasa peduli terhadap lingkungan sekitarnya.

Keempat, Adapun hambatan peneliti dalam melaksanakan penelitian tindakan kelas ini yaitu:

a. Dalam penelitian ini guru sulit untuk mengatur alokasi waktu pada saat pengerjaan produk di dalam kelas.

b. Dalam melaksanakan penelitian ini guru harus mencari media pembelajaran dengan materi yang relevan agar siswa termotivasi untuk menjaga lingkungannya.

c. Pada saat siklus I siswa mengalami kebingungan dalam memilih barang-barang bekas yang harus digunakan.

d. Banyaknya siswa yang yang keberatan dengan pembagian kelompok yang dilakukan secara acak membuat guru harus memberikan motivasi ekstra agar siswa mau mengerjakan tugas kelompoknya dan tidak saling mengandalkan.

Berangkat dari permasalahan-permasalahan tersebut, maka solusi yang telah dilakukan diantaranya:

a. Membuat perencanaan yang matang agar waktu dapat dimanfaatkan seefektif mungkin.

b. Membuat persiapan yang matang untuk mencari media yang tepat dengan materi yang akan di sajikan.

c. Guru memberikan arahan yang lebih jelas dan memberikan contoh agar siswa tidak mengalami kebingungan untuk memilih barang bekas yang akan digunakan.

d. Melakukan pendekatan personal dan menciptakan kegiatan pembelajaran di kelas lebih menarik.

e. Meminta saran kepada guru mitra ketika menghadapi kesulitan-kesulitan lainnya. 


\section{DAFTAR PUSTAKA}

\section{A. Buku}

Ekawarna. (2013). Penelitian Tindakan Kelas. Jakarta: Referensi GP (Press Group). Elizariyati. (2011). Penggunaan Metode Pemberian Tugas Pada Pembelajaran IPS Dalam Rangka Peningkatan Hasil Belajar Siswa. (Skripsi). Fakultas Ilmu Pendidikan, Universitas Pendidikan Indonesia

Goleman D., Bennet L., Barlow Z.. (2012). Eco Literate, How Educators Are Cultivating Emotional, Social and Ecological Intellegence. San Francisco: Jossey-Bass.

Kusuma, Indra. (2014). Pengembangan Karakter Siswa yang Peduli Lingkungan Melalui Penerapan 3R (reduce, reuse, recycle) dalam pembelajaran IPS. (skripsi) Fakultas Pendidikan Ilmu Pengetahuan Sosial, Universitas Pendidikan Indonesia. Sapriya, dkk. (2008). Konsep Dasar IPS. Bandung: Laboratorium PKN UPI

\section{B. Jurnal}

Lestari, L. (2013). Meningkatkan Prestasi Belajar Bahasa Indonesia Dengan Metode Pemberian Tugas Belajar dan Resitasi Siswa Kelas Vi Sekolah Dasar. Jurnal, hlm. 1-10.

Pramanta, S. (2012). Pengaruh Pembelajaran Model Resitasi Terhadap Prestasi Belajar Siswa Pada Mata Pelajaran Sistem Kelistrikan Otomotif Di SMK Muhammadiyah 3 Yogyakarta. Jurnal, hlm. 1-8. 